\title{
A REVIEW OF THE USE OF REMOTE SENSING FOR MONITORING AND QUANTIFYING CARBON SEQUESTRATION IN MARGINAL LANDS
}

\author{
REVISIÓN SOBRE EL USO DE LA TELEDETECCIÓN EN LA MONITORIZACIÓN Y PREDICCIÓN DEL \\ ALMACENAMIENTO DE CARBONO EN TIERRAS MARGINALES \\ Juan Pedro Carbonell-Riveraa, ${ }^{a}$, Javier Estornella, Luis A. Ruiza, Alfonso Abad ${ }^{b}$, Bettina Felten ${ }^{c}$, \\ Jesús Torralba ${ }^{a}$ \\ a Geo-Environmental Cartography and Remote Sensing Group (CGAT), Universitat Politècnica de València, Camino de Vera s/n, 46022 \\ Valencia, Spain. juacarri@upv.es; jaescre@cgf.upv.es; laruiz@cgf.upv.es; jetorpe@upv.es \\ ${ }^{\text {b }}$ Cesefor (Centro de Servicios y Promoción Forestal y de su Industria de Castilla y León). Polígono Industrial las Casas, calle C, \\ parcela 4, 42005 Soria, Spain. alfonso.abad@cesefor.com \\ c Industrieanlagen-Betriebsgesellschaft mbH (IABG), Hermann-Reichelt-Srt. 3, 01109 Dresden, Germany. Felten@iabg.de
}

\begin{abstract}
:
In recent years, Remote Sensing (RS) and its derived products have been used as a key tool for the detection, monitoring, management and future use of Marginal Lands (ML). Currently, there is no single, universally accepted definition of the term and there is a wide variety of synonyms. In this paper, we conduct a compilation of synonyms and meanings that encompass the term, as well as propose a definition. To reach this objective, an overview of the state of the art of ML is done, visualising trends by science maps, based on bibliographic data of established research journals, found in Google Scholar, Web of Science (WoS) and Scopus search engines. The bibliographic review carried out shows that the study of ML has traditionally been carried out with an ad hoc basis focused on the objective to be achieved, this aspect and other knowledge gaps are discussed to analyse the global study of ML. Due to the broad spectrum of uses in which ML have been studied, the work has been focused on RS for monitoring and characterizing ML, focusing on two different aspects: (i) satellite monitoring of marginal lands; and (ii) determining carbon sequestration potential of marginal lands using remote sensing.
\end{abstract}

Key words: marginal lands, remote sensing, carbon sequestration, land use

\section{Resumen:}

En los últimos años, la teledetección y sus productos derivados se han utilizado como herramienta clave para la detección, seguimiento, gestión y uso futuro de las tierras marginales (ML). Actualmente, no existe una definición única y universalmente aceptada del término y existe una gran variedad de sinónimos. En este artículo llevamos a cabo una recopilación de sinónimos y significados que engloban el término, además de proponer una definición universal. Para alcanzar este objetivo, se realiza un resumen del estado del arte de las ML, visualizando las tendencias mediante mapas científicos, basadas en datos bibliográficos de revistas de investigación consolidadas, encontradas en los buscadores Google Scholar, Web of Science (WoS) y Scopus. La revisión bibliográfica realizada muestra que el estudio de las ML se ha realizado tradicionalmente con una base ad hoc centrada en el objetivo a alcanzar. Se discute este aspecto y otras lagunas de conocimiento para analizar el estudio global de las tierras marginales. Debido al amplio espectro de usos en que se han estudiado las tierras marginales, los trabajos se han centrado en la teledetección para su seguimiento y caracterización, centrándose en dos aspectos diferentes: (i) el seguimiento por satélite de las tierras marginales; y (ii) determinación de su potencial en el almacenamiento de carbono mediante teledetección.

Palabras clave: tierras marginales, teledetección, captura de carbono, uso del suelo

\section{Introduction}

The international sustainable development goals set by the United Nations General Assembly (The Millennium Development Goals (United Nations 2000); The Sustainable Development Goals (United Nations 2015)) have encouraged studies to achieve a better and more sustainable future for everyone. In this sense, the objective of taking urgent action to combat climate change and its impacts has promoted the scientific community to consider marginal lands (ML) as an opportunity in the face of limited arable land resources. (Koonin 2006; Kurbanov et al. 2007; Milbrandt \& Overend 2009; Kang et al. 2013). In recent years, there has been an increased interest in the potential use of ML for biofuels, food security or carbon sequestration (Gelfand et al. 2013; Kang et al. 2013; Emery et al. 2017; Qureshi 2017). This trend has led to an increase in the number of studies identifying and evaluating the use of ML. Unfortunately, many of these studies have developed their own definition of the concept, differing across epoch, discipline and geographical areas (Liu et al. 2011; Lewis \& Kelly 2014).

`Corresponding Author: Juan Pedro Carbonell-Rivera, juacarri@upv.es 
In addition, the term $\mathrm{ML}$ is often related to other terms that could be considered interchangeable. This lack of a unified concept of the term has also meant that the methods for identifying and monitoring ML have been diverse and focused on an ad hoc basis. According to Kang et al. in 2013 , there is no widely accepted method for evaluating $M L$ and generally the methods used are qualitative and empirical, and some of them are very subjective.

In recent years, the use of remote sensing (RS) has allowed the characterisation of $\mathrm{ML}$ based mostly on biophysical characteristics, reducing the subjectivity of the studies (Nalepa \& Bauer 2012). However, these studies have implemented widely differing methodologies to study ML, making necessary a compilation of the techniques used, as well as a study of the trends in remote sensing applied to the study of $\mathrm{ML}$.

This article aims to compile the related terms which have been used interchangeably with the term ML, as well as the different descriptions that have been given to these terms. In this sense, a global description of the term is proposed. In addition, a literature review of the use of RS on ML is carried out. This work has been focused on one of the most currently interesting uses of $M L$ for their contribution to climate change mitigation, the use of $\mathrm{ML}$ as carbon storage.

\section{Analogous concepts}

The concept $\mathrm{ML}$ is related with different terms that have been used as synonyms. The lack of an overall definition has meant that the concept has been used in a vague and non-concise way, leading to the use of different adjectives to talk about the same concept (Milbrandt \& Overend 2009). Some of these terms are "abandoned lands", "degraded lands", "idle lands", "set-aside lands", "underutilized lands", "unproductive lands", or "waste lands" (Lal 1991; Sugrue 2008; Wiegmann et al. 2008; Kang et al. 2013).

To analyse the use of each term in the scientific and academic field, an analysis of the results in Google Scholar, WoS (using the databases belonging to the Core Collection of Clarivate Analytics) and Scopus search engines was carried out for each term. These search engines are the most widely used in the search for academic and scientific literature (Martín-Martín et al. 2018).

The results of this search are shown in Table 1. A global analysis shows that Google Scholar systematically yields a higher number of indexed publications compared to WoS and Scopus. These results are due to Google's method of indexing documents. Google Scholar uses an automated method that indexes any document with a seemingly academic structure, giving an additional view of the scientific and scholarly literature compared to WoS and Scopus (Martín-Martín et al. 2018).

Analysing the table in depth, the most used terms in the Google Scholar search engine are "waste lands" and "abandoned lands", followed by "marginal lands". In the WoS search the most frequently used term is "waste lands", while the terms "abandoned lands", "degraded lands" and "marginal lands" are used less frequently. Finally, the Scopus search engine agrees with WoS in determining the term "waste lands" as the most used term, followed by the terms "abandoned lands", "degraded lands" and "marginal lands". The results also show that, regardless of the search engine used, the terms "degraded lands", "idle lands", "set-aside lands", "underutilised lands" and "unproductive lands" are not commonly used.

Table 1: Search results by search term and search engine.

\begin{tabular}{c|c|c|c} 
Search term & $\begin{array}{c}\text { Google } \\
\text { Scholar }\end{array}$ & $\begin{array}{c}\text { Web of } \\
\text { Science }\end{array}$ & Scopus \\
\hline Abandoned lands & $1,250,000$ & 11,603 & 8,088 \\
Degraded lands & 389,000 & 17,100 & 9,982 \\
Idle lands & 257,000 & 1,139 & 523 \\
Marginal lands & 842,000 & 11,375 & 7,800 \\
Set-aside lands & 317,000 & 1,765 & 1,085 \\
Underutilized lands & 51,100 & 584 & 516 \\
Unproductive lands & 144,000 & 703 & 518 \\
Waste lands & $1,420,000$ & 46,564 & 35,940
\end{tabular}

In this sense, it is also interesting to study the number of citations received by the most relevant paper according to each search term used. To this end, a search was carried out for the most cited papers according to WoS by search term. In the case of the term "abandoned lands" the most cited paper explores the future of abandoned farmlands in Europe (Verburg \& Overmars 2009), obtaining 451 citations. Regarding the term "degraded lands", the most relevant document deals with restoring forests and ecosystem services on degraded lands (Chazdon 2008), obtaining 918 citations. Also noteworthy for this term is a paper on catalysing the regeneration of native forests on degraded tropical lands (Parrotta et al. 1997), which gets 416 citations. In relation to the term "marginal lands", the paper with the most citations is about sustainable bioenergy production from ML (Gelfand et al. 2013), with 426 citations. Finally, a search for the term "waste lands" reveals that the most cited paper is not related to the scope of this study, but to plastic waste inputs from land into the ocean (Jambeck et al. 2015), a paper with 3,073 citations, and in which it can be seen that the title contains the search term, creating confusion in WoS. This fact is repeated in the following search results, as the papers with the most citations have a different final scope, finding that the paper with the most citations that includes the "waste lands" concept studied in this research has less than 30 citations. Analysing the number of citations for the rest of the search terms, we find that the most relevant publications have no more than 30 citations either.

In order to extent this analysis, we carried out a bibliometric map with the search results obtained from the different synonyms of the term ML (Fig. 1). To produce this map, titles and abstracts of the 500 articles with the highest relevance according to WoS were obtained for each of the synonymous terms showed in Table 1, analysing a total of 4000 items. This bibliometric map shows the number of publications where there is a cooccurrence between two terms. Thus, the higher the number of co-occurrences of a term with other terms, the larger display size of the term, as well as higher number of links (van Eck and Waltman 2010). 


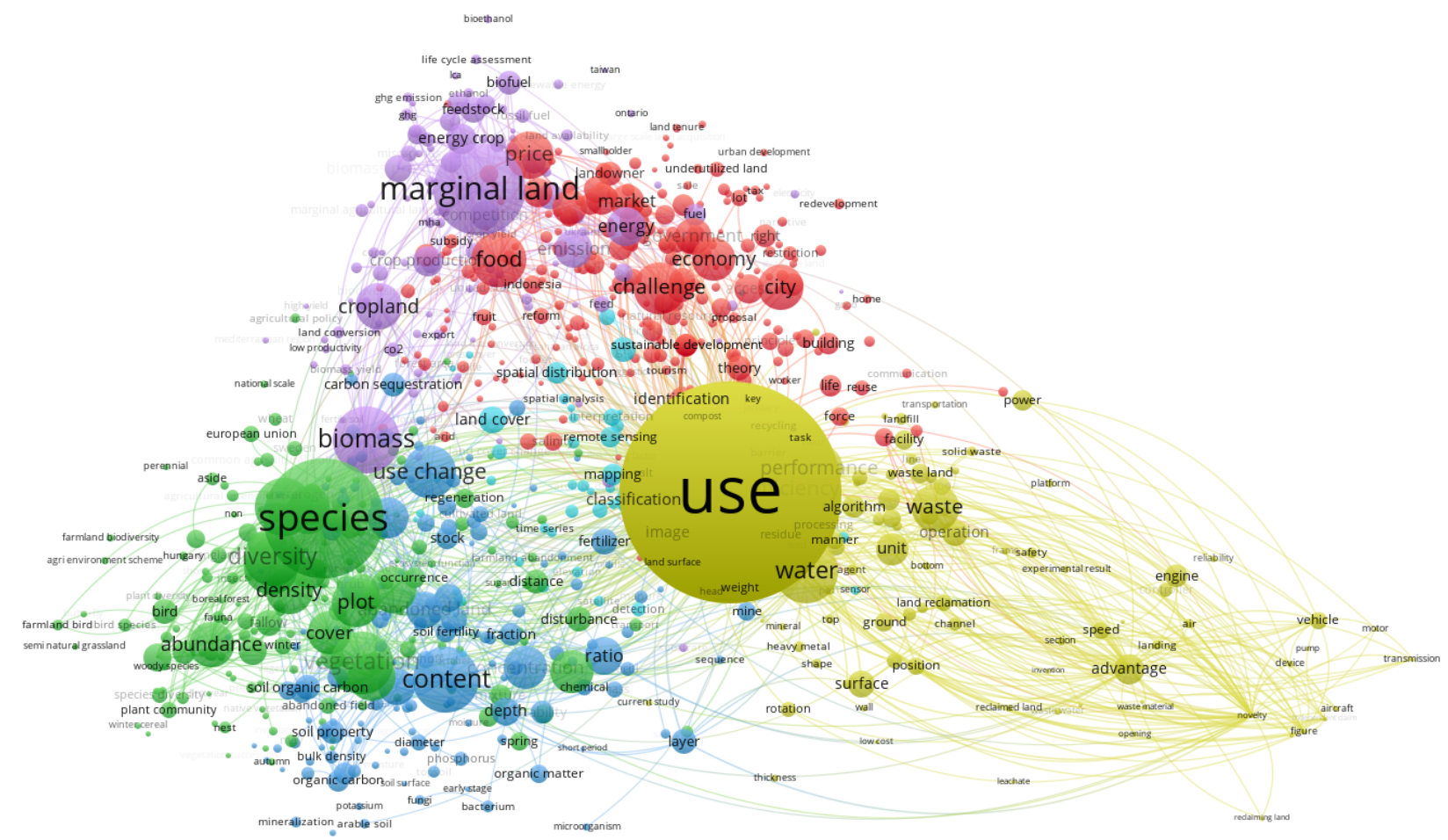

Figure 1: Bibliometric network of co-ocurrences found in the titles and abstract of the first 500 search results offered for the terms "Marginal lands", "Unproductive lands", "Waste lands", "Idle lands", "Abandoned lands", "Underutilized lands", "Degraded lands" and "Set-aside lands" in WoS.

The bibliometric map also shows a cluster of the literary network. This cluster is calculated using the following formula (Duan et al. 2020), Eq. (1) and (2):

$$
\begin{aligned}
& V\left(c_{1}, \ldots, c_{n}\right)=\frac{1}{2 m} \sum_{i<j} \delta\left(c_{i}, c_{j}\right) \omega_{i j}\left(c_{i j}-\gamma \frac{c_{i} c_{j}}{2 m}\right) \\
& \omega_{i j}=\frac{2 m}{c_{i}} c_{j}
\end{aligned}
$$

Where:

$$
\begin{aligned}
& c_{i}=\text { cluster of the element } \mathrm{i} \\
& \gamma=\text { resolution of clustering }
\end{aligned}
$$

In this study, the value of the resolution clustering was set to 1.0. Analysing the bibliometric map obtained, we can see that 6 clusters have been created.

The first cluster, in red, has 239 items related to economic terms, being the most relevant the term "food". This term is linked to others such as "challenge", "price", "economy" or "government". In this regard, the relationship between these items highlights the relevance of government decisions not to produce biofuels on existing agricultural lands, to avoid an indirect land use change which could increase food prices, changing local economies (Ahlgren and Di Lucia 2014). In this cluster is located the term "underutilized" relating it to a purely economic aspect.

The second cluster showed in green colour has 175 terms related to ecologic terms. It includes items related to flora, such as "species" (being the item with a higher number of co-occurrences), "vegetation", "diversity", "density", "agricultural policy" or abundance. In this cluster we find the term "set-aside lands", which is normally used to refer to land temporarily unused due to political interventions (Dauber et al. 2012).
The third cluster is composed of 144 items in indigo blue colour. This cluster is related with natural and agricultural terms, being "content" and "use change" the most relevant items. This cluster includes terms related to soil characteristics such as "soil fertility", "soil organic carbon", or "organic matter". In this cluster we find the ML synonym "abandoned land". This fact highlights the use of this term, which is usually designated for lands that have had a previous anthropic use, mainly in natural resources and agriculture, but where due to the low quality of the soil they have been left uncultivated (Imbrenda et al. 2014).

The fourth cluster is shown in purple, with 111 items related with energy harvesting. In this cluster the item with the most co-occurrences is the term ML, which is widely related to terms such as biomass, biofuel, energy crop, or cropland, all of them related to the use of ML for biofuel production.

The fifth cluster, in yellow, has 104 items. It presents as the item with the highest co-occurrence the term "use". To this cluster belongs the term "waste land". This term is used to identify the lands with unfavourable physical and biological conditions (Wiegmann et al. 2008). In this sense, terms such as "heavy metal", "solid waste", or "residue" are found in this cluster. Examples of such land are mainly brownfield sites, such as quarries or other types of mining areas with the presence of tailings dumps, lands that are not currently in use that may be potentially contaminated.

Finally, the sixth cluster is represented in cyan colour, having only 49 items related with geomatics. The item with the highest number of co-occurrences is the term "land cover", which is related to other terms such as "GIS", "remote sensing", "classification" or "mapping", 
relating the keywords of the tools and techniques used in the identification and management of ML.

From this analysis, we can extract that of the synonymous terms analysed, the term with the highest number of cooccurrences was "marginal land". Other synonymous terms which are widely used, such as "abandoned lands" and "waste lands", have less weight in the search for cooccurrences. In the case of "abandoned lands", the term is limited by the previous anthropic use. Whereas the term "waste lands" is constrained by the specificity of the concept, since waste lands are defined as empty and desolate lands, with no sign of life or growth.

\section{Meanings and definitions}

The overall vision of the term "marginal land" was initially related to land uses that are not economically profitable. One of the first definitions of the concept was made by Hollander in 1895, defining ML as the poorest land used above the margin of profitability. Similarly, Peterson and Galbraith proposed in 1932 a purely economic concept of the term, defining $M L$ as farmland where income is equal to (or less than) the cost of production. It was not until the late 20th century when it was proposed an environmental approach of the concept, referring to $\mathrm{ML}$ as those with low production, which are unsuitable for agricultural practices and ecosystem function (Heimlich 1989).

Since the beginning of the 21st century, the growing scientific interest in the identification and management of ML has led numerous authors to define the term. In 2006 Schroers defined the concept as the area where production is not profitable under certain conditions related to agricultural policies, farming techniques, legal and macroeconomic conditions. The author provides an economic definition of the term, including a political perspective, which was necessary due to the application of agricultural subsidies that began to develop in the mid20th century, such as the European Common Agricultural Policy.

Milbrandt and Overendin in 2009 gave a technical definition of the term, stating that $\mathrm{ML}$ are characterised by poor climate, poor physical characteristics, or difficult cultivation. An approach that Schweers et al. expanded in 2011, indicating that land marginality is due to the longterm loss of ecosystem function and services, caused by factors from which the system cannot recover unaided. This definition implies that the determination of land as marginal must be purely technical and must be based on multi-temporal studies, allowing the characterisation over a long period.

In 2012, Liu et al. proposed a mercantilist view of the term, focused on the generation of biofuels. The author indicates that $\mathrm{ML}$ are those not suitable for crop production, but ideal for the growth of energy crops with high stress resistance. One year later, Kang et al. indicated that $\mathrm{ML}$ are usually characterised by low economic and productive returns or those with severe limitations for agricultural cultivation. Following this view, Shortall in 2013 also proposed a similar definition, stating that all ML must meet three requirements. These lands cannot be used for food production, they must be characterised by their low quality and their economic use must be marginal.
In contrast, Lewis and Kelly in 2014 provided a technical definition of the term, stressing that $\mathrm{ML}$ areas are characterised by a low nutrient content, poorly drained soils with reduced water availability and steep slopes. Following this approach, Blanco-Canqui in 2016 indicated that $\mathrm{ML}$ are lands that have physical and chemical problems, or are uncultivated, or negatively affected by climatic conditions.

One of the most recent definitions was proposed by Schröder et al. in 2018 indicating ML are those that have lost their ecological and/or economic value to the community and their degradation is increasing over time.

A review of the term over the years shows that most of the authors have defined it by focusing merely on the economic aspect. This definition is explained by its initial economic nature in a context of economic crisis context.

At the end of the 20th century, a greater environmental awareness began to emerge and factors such as ozone depletion or climate change have caused a change in global consciousness (Leiserowitz 2007), affecting and evolving the term ML to a more environmental approach. The term "marginal land" is a living concept, changing over time, which has incorporated other anthropic aspects such as cultural, social, or political factors (Baldock 1996; Mehretu et al. 2000; Krcmar et al. 2005; Kang et al. 2013). One of the most relevant aspects to consider is the temporal variability of the concept of marginal land, since what may be classified as marginal land now may not be so in the future (i.e., economic crises may make land use profitable again, agricultural policies). The temporal dynamics on the land should be explicitly included in the definition as the phenomenon of marginality should be stable over time, being due to degradation (natural) or abandonment (anthropic) processes over a long period of time. In this sense, the definition must be global to adapt to the anthropic circumstances and environmental conditions of each region. All these constrains are interrelated with each other as shown in the Figure 2.

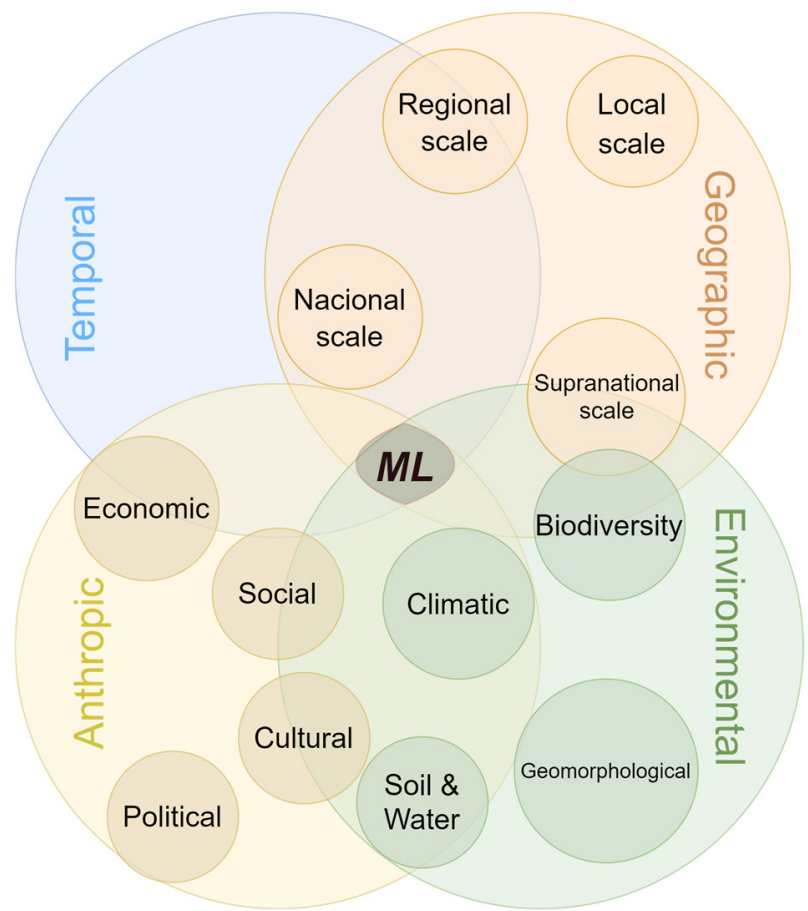

Figure 2: Diagram of the different factors affecting the Marginal Lands (ML) concept. 
Our proposed definition of ML is "Land without change over time, with significant constraints either cultural, economic, environmental, political or social, where a land use change would result in a gain in any of these aspects."

\section{Remote sensing and marginal lands}

RS and modern interpretation techniques are being widely used in recent years for objective identification, monitoring, management and future utilization of underutilized lands at a regional or global scale (Nalepa \& Bauer 2012). Due to the broad spectrum in which remote sensing has been applied to marginal lands, we conducted an overview of the most relevant papers on the topics "satellite monitoring of marginal lands" and "carbon sequestration potential of marginal lands using remote sensing".

\subsection{Satellite monitoring of marginal lands}

One of the first studies that applied RS for monitoring ML was published by W. Ray et al. in 1993, who identified agricultural areas that were abandoned in south-eastern California in the mid-20th century due to the rising price of electricity needed to pump irrigation water. To achieve this purpose, polarimetric SAR was used to detect ploughed concentric circular planting furrows, as well as the NDVI index obtained from Landsat-5 TM images.

The use of RS has provided information on land cover and land use patterns, making possible the identification of gradual land abandonment from multi-temporal comparisons. Witmer and O'Loughlin in 2009, conducted a study of the effects of the war in Bosnia-Herzegovina on the agricultural environment. Using Landsat-5 TM and Quickbird imagery, multi-temporal studies were carried out to identify agricultural land that was abandoned due to the war. In this paper, the author highlights the importance of RS data for tracking the course of conflicts and assessing their long-term impacts.

Hermosilla et al. proposed in 2012 a methodology to identify abandoned agricultural plots in northwest Spain. The classification of these plots was object-oriented, using spectral, textural, structural and shape features extracted from orthophotos that were used as inputs for three different classification methods (decision trees, linear discriminant analysis and support vector machine). This methodology showed a high capability of the objectbased image classification techniques as a tool for updating and managing ML.

Milenov et al. in 2014 developed the "Abandoned agricultural land" tool to detect potentially abandoned agricultural land based on SPOT multi-temporal data. The objective of this study was to detect abandoned agricultural land to corroborate the correct functioning of the European Common Agricultural Policy, verifying that the expansion of abandoned agricultural lands was avoided and that they were reactivated.

Löw et al. in 2015 conducted a study with the same objective, mapping abandoned agricultural land, but for a different purpose, to monitor and limit crop abandonment in Central Asia. For this, Landsat-5 TM, Landsat-8 OLI and RapidEye imagery were classified using Random forest and support vector machines. Liu et al. (2015) studied changes in land use of ML using Landsat-7 ETM+ and SPOT5 imagery. Since the early 1960s, oil exploration in the Yellow River delta (China) has led to the fragmentation of protected wetlands. In this study it was reported how the ML generated by oil extraction are restored to their original environmental function.

The overall assessment of the papers on satellite monitoring of ML shows how studies have addressed a wide range of issues, but there are currently no mechanisms that routinely generate accurate, consistent and regular data on land degradation at the national scale (Giuliani et al. 2020). The large volumes of freely and openly available satellite Earth observation data are not used to create a comprehensive ML monitoring product.

\subsection{Carbon sequestration potential of marginal lands using remote sensing}

RS technology has the potential to be useful for frequent monitoring of carbon sequestration projects (Brown 1996). A wide variety of RS missions have been used to quantify carbon sequestration, as AVHRR, Landsat (MSS and TM), SPOT, AVIRIS, GEDI or Sentinel (Brown 1996; Castaldi et al. 2019). In this sense, the methodology to obtain the carbon sequestration of $\mathrm{ML}$ does not differ from others that assess this variable in other types of land use. There is a great interest to calculate the potential that reforestation or afforestation of ML would have on its use as carbon stock.

In 2000 , Silver et al. published one of the first papers on the potential for carbon sequestration through reforestation of abandoned lands. In his paper they conclude that forests growing on abandoned agricultural land accumulate biomass faster than other land uses, while soil carbon accumulates faster on sites that were cleared without agricultural development. This opens a new research focus, long-term carbon sequestration potential for the mitigation of atmospheric emissions of $\mathrm{CO} 2$.

In 2007, Potter et al. conducted satellite-derived estimations of the carbon sequestration potential through afforestation of ML in the United States. This paper reported one of the first estimations of carbon sequestration by afforesting ML. The study was conducted using direct inputs of satellite data from the AVHRR sensor into the NASA-CASA carbon model to estimate monthly variability in net primary production and potential biomass accumulation rates. The paper concludes that afforestation of ML in the US would offset at least one-fifth of annual carbon emissions in the country.

DiRocco et al. in 2014, conducted a discussion on the best land-use options for carbon-based management in $\mathrm{ML}$, emphasising the need for current and postrestoration management. In this regard, the author points out the uncertainty in global carbon stock estimations with current techniques, highlighting the need for continuous improvement of these techniques.

\section{Conclusions}

In this paper, a search has been carried out for analogous concepts to the term $\mathrm{ML}$, concluding that there are different terms that are more commonly used for certain topics, being the term ML the one that encompasses them all. The meaning of this term has varied with respect to 
the political, economic, socio-cultural and environmental context in which it has been used. The lack of a fixed definition has led to the term being used with an ad hoc and independent view of each paper, rather than a global one. In this paper, we proposed a definition that considers all these costrains, making a dynamic definition from a temporal point of view and independent of the geographical location in which it is applied.

$\mathrm{RS}$ is becoming a key element in the identification and management of $\mathrm{ML}$, making its use indispensable in any large-scale study. In this sense, the biggest challenge facing remote sensing is that there is no visible spectral response or pattern that is directly associated with $\mathrm{ML}$. Therefore, studies that have considered its use for carbon identification, management or quantification have used different methodologies and sensors.

\section{Acknowledgements}

This work was supported by the Spanish Ministerio de Economía, Industria y Competitividad through the scholarship for Training of Research Staff BES-2017081920 and the European Commission through the H2020-MSCA-RISE-2018 MAIL project under Grant Agreement 823805.

\section{References}

AHLGREN, S., and DI LUCIA, L. 2014. Indirect land use changes of biofuel production-a review of modelling efforts and policy developments in the European Union. Biotechnology for biofuels, 7, pp. 1-10.

BALDOCK, D. 1996. Farming at the Margins. IEEP and LEI-DLO.

BLANCO-CANQUI, H. 2016. Growing dedicated energy crops on marginal lands and ecosystem services. Soil Science Society of America Journal, 80, pp. 845-858.

BROWN, K. 1996. The utility of remote sensing technology in monitoring carbon sequestration agroforestry projects. Winrock International.

CASTALDI, F., HUENI, A., CHABRILLAT, S., WARD, K., BUTTAFUOCO, G., BOMANS, B., VREYS, K., BRELL, M., and VAN WESEMAEL, B. 2019. Evaluating the capability of the Sentinel 2 data for soil organic carbon prediction in croplands. ISPRS Journal of Photogrammetry and Remote Sensing, 147, pp. 267-282.

CHAZDON, R. L. 2008. Beyond deforestation: restoring forests and ecosystem services on degraded lands. Science, $\mathbf{3 2 0}$, pp. $1458-1460$.

DAUBER, J., BROWN, C., FERNANDO, A. L., FINNAN, J., KRASUSKA, E., PONITKA, J., STYLES, D., THRÄN, D., VAN GROENIGEN, K. J., and WEIH, M. 2012. Bioenergy from "surplus" land: environmental and socio-economic implications. BioRisk, 7(5).

DIROCCO, T. L., RAMAGE, B. S., EVANS, S. G., and POTTS, M. D. 2014. Accountable accounting: Carbon-based management on marginal lands. Forests, 5, pp. 847-861.

DUAN, P., WANG, Y., and YIN, P. 2020. Remote sensing applications in monitoring of protected areas: A bibliometric analysis. Remote Sensing, 12(772).

EMERY, I., MUELLER, S., QIN, Z., and DUNN, J. B. 2017. Evaluating the potential of marginal land for cellulosic feedstock production and carbon sequestration in the United States. Environmental science \& technology, 51, pp. 733-741.

GELFAND, I., SAHAJPAL, R., ZHANG, X., IZAURRALDE, R. C., GROSS, K. L., and ROBERTSON, G. P. 2013. Sustainable bioenergy production from marginal lands in the US Midwest. Nature, 493(7433), pp. 514-517.

GIULIANI, G., CHATENOUX, B., BENVENUTI, A., LACROIX, P., SANTORO, M., and MAZZETTI, P. 2020. Monitoring land degradation at national level using satellite Earth Observation time-series data to support SDG15-exploring the potential of data cube. Big Earth Data, 4, pp. 3-22.

HEIMLICH, R. E. 1989. Productivity and erodibility of US cropland. US Department of Agriculture, Economic Research Service.

HERMOSILLA, T., DÍAZ-MANSO, J. M., RUIZ, L. A., RECIO, J. A., FERNÁNDEZ-SARRÍA, A., and FERRADÁNSNOGUEIRA, P. 2012. Analysis of parcel-based image classification methods for monitoring the activities of the Land Bank of Galicia (Spain). Applied Geomatics, 4, pp. 245-255.

HOLLANDER, J. H. 1895. The concept of marginal rent. The Quarterly Journal of Economics, 9, pp. 175-187.

IMBRENDA, V., D'EMILIO, M., LANFREDI, M., RAGOSTA, M., and SIMONIELLO, T. 2014. Indicators of land degradation vulnerability due to anthropic factors: tools for an efficient planning. In Sustainable Practices: Concepts, Methodologies, Tools, and Applications, IGI Global, pp. 1400-1413.

JAMBECK, J. R., GEYER, R., WILCOX, C., SIEGLER, T. R., PERRYMAN, M., ANDRADY, A., NARAYAN, R., and LAW, K. L. 2015. Plastic waste inputs from land into the ocean. Science, 347, pp. 768-771.

KANG, S., POST, W. M., NICHOLS, J. A., WANG, D., WEST, T. O., BANDARU, V., and IZAURRALDE, R. C. 2013. Marginal lands: concept, assessment and management. Journal of Agricultural Science, 5, pp. 129.

KOONIN, S. E. 2006. Getting serious about biofuels. Science (New York, NY), 311(5760), pp. 435-435. 
KRCMAR, E., VAN KOOTEN, G. C., and VERTINSKY, I. 2005. Managing forest and marginal agricultural land for multiple tradeoffs: compromising on economic, carbon and structural diversity objectives. Ecological Modelling, 185, pp. 451468.

KURBANOV, E., VOROBYOV, O., GUBAYEV, A., MOSHKINA, L., and LEZHNIN, S. 2007. Carbon sequestration after pine afforestation on marginal lands in the Povolgie region of Russia: A case study of the potential for a Joint Implementation activity. Scandinavian Journal of Forest Research, 22, pp. 488-499.

LAL, R. 1991. Tillage and agricultural sustainability. Soil and Tillage Research, 20, pp. 133-146.

LEISEROWITZ, A. 2007. International public opinion, perception, and understanding of global climate change. Human development report, 2008, pp. 1-40.

LEWIS, S. M., and KELLY, M. 2014. Mapping the potential for biofuel production on marginal lands: differences in definitions, data and models across scales. ISPRS International Journal of Geo-Information, 3, pp. 430-459.

LIU, Q., LIU, G., HUANG, C., SHI, L., and ZHAO, J. 2015. Monitoring vegetation recovery at abandoned land. 20158 th International Congress on Image and Signal Processing (CISP), pp. 104-108.

LIU, T., MA, Z., MCCONKEY, B., KULSHRESHTHA, S., HUFFMAN, T., GREEN, M., LIU, J., DU, Y., and SHANG, J. 2012. Bioenergy production potential on marginal land in Canada. 2012 First International Conference on AgroGeoinformatics (Agro-Geoinformatics), pp. 1-6.

LIU, T. T., MCCONKEY, B. G., MA, Z. Y., LIU, Z. G., LI, X., and CHENG, L. L. 2011. Strengths, weaknessness, opportunities and threats analysis of bioenergy production on marginal land. Energy Procedia, 5, pp. 2378-2386.

LÖW, F., FLIEMANN, E., ABDULLAEV, I., CONRAD, C., and LAMERS, J. P. A. 2015. Mapping abandoned agricultural land in Kyzyl-Orda, Kazakhstan using satellite remote sensing. Applied Geography, 62, pp. 377-390.

MARTÍN-MARTÍN, A., ORDUNA-MALEA, E., THELWALL, M., and LÓPEZ-CÓZAR, E. D. 2018. Google Scholar, Web of Science, and Scopus: A systematic comparison of citations in 252 subject categories. Journal of informetrics, 12, pp. $1160-1177$.

MEHRETU, A., PIGOZZI, B. W., and SOMMERS, L. M. 2000. Concepts in social and spatial marginality. Geografiska Annaler: Series B, Human Geography, 82, pp. 89-101.

MILBRANDT, A., and OVEREND, R. P. 2009. Assessment of biomass resources from marginal lands in APEC economies. National Renewable Energy Lab.(NREL), Golden, CO (United States).

MILENOV, P., VASSILEV, V., VASSILEVA, A., RADKOV, R., SAMOUNGI, V., DIMITROV, Z., and VICHEV, N. 2014. Monitoring of the risk of farmland abandonment as an efficient tool to assess the environmental and socio-economic impact of the Common Agriculture Policy. International journal of applied earth observation and geoinformation, 32, pp. 218-227.

NALEPA, R. A., and BAUER, D. M. 2012. Marginal lands: the role of remote sensing in constructing landscapes for agrofuel development. Journal of Peasant Studies, 39, pp. 403-422.

PARROTTA, J. A., TURNBULL, J. W., and JONES, N. 1997. Catalyzing native forest regeneration on degraded tropical lands. Forest Ecology and Management, 99, pp. 1-7.

PETERSON, G. M., and GALBRAITH, J. K. 1932. The concept of marginal land. Journal of Farm Economics, 14, pp. 295310.

POTTER, C., KLOOSTER, S., HIATT, S., FLADELAND, M., GENOVESE, V., and GROSS, P. 2007. Satellite-derived estimates of potential carbon sequestration through afforestation of agricultural lands in the United States. Climatic Change, 80, pp. 323-336.

QURESHI, A. S. 2017. Sustainable use of marginal lands to improve food security in the United Arab Emirates. Journal of Experimental Biology and Agricultural Sciences, 5.

RAY, T. W., FARR, T. G., BLOM, R. G., and CRIPPEN, R. E. 1993. Monitoring land use and degradation using satellite and airborne data.

SCHRÖDER, P., BECKERS, B., DANIELS, S., GNÄDINGER, F., MAESTRI, E., MARMIROLI, N., MENCH, M., MILLAN, R., OBERMEIER, M. M., and OUSTRIĖRE, N. 2018. Intensify production, transform biomass to energy and novel goods and protect soils in Europe-a vision how to mobilize marginal lands. Science of the total environment, 616, pp. 1101-1123.

SCHROERS, J. O. 2006. Towards the development of marginal land use depending on the framework of agricultural market, policy and production techniques. University of Giessen, Germany.

SCHWEERS, W., BAI, Z., CAMPBELL, E., HENNENBERG, K., FRITSCHE, U., MANG, H.-P., LUCAS, M., LI, Z., SCANLON, A., and CHEN, H. 2011. Identification of potential areas for biomass production in China: Discussion of a recent approach and future challenges. Biomass and bioenergy, 35, pp. 2268-2279. 
SHORTALL, O. K. 2013. "Marginal land" for energy crops: Exploring definitions and embedded assumptions. Energy Policy, 62, pp. 19-27.

SILVER, W. L., OSTERTAG, R., and LUGO, A. E. 2000. The potential for carbon sequestration through reforestation of abandoned tropical agricultural and pasture lands. Restoration ecology, 8, pp. 394-407.

SUGRUE, A. 2008. Bioenergy production on marginal and degraded land: the potential social impacts. Issue Paper prepared for the Joint International Workshop on High Nature Value Criteria and Potential for Sustainable Use of Degraded Lands-June, 30.

UNITED NATIONS. 2000. United Nations Millennium Declaration (A/RES/55/2). Available: https://www.un.org/en/development/desa/population/migration/generalassembly/docs/globalcompact/A_RES_55_2.p df $[6 / 17,2021]$.

UNITED NATIONS. 2015. Transforming our world: the 2030 Agenda for Sustainable Development (A/RES/70/1). SDGs Transform Our World. Available: https://www.un.org/ga/search/view_doc.asp?symbol=A/RES/70/1\&Lang=E [6/17, 2021].

VERBURG, P. H., and OVERMARS, K. P. 2009. Combining top-down and bottom-up dynamics in land use modeling: exploring the future of abandoned farmlands in Europe with the Dyna-CLUE model. Landscape ecology, 24, pp. 11671181.

WIEGMANN, K., HENNENBERG, K. J., and FRITSCHE, U. R. 2008. Degraded land and sustainable bioenergy feedstock production. Joint international workshop on high nature value criteria and potential for sustainable use of degraded lands.

WITMER, F., and O'LOUGHLIN, J. 2009. Satellite Data Methods and Application in the Evaluation of War Outcomes: Abandoned Agricultural Land in Bosnia-Herzegovina After the 1992-1995 Conflict. Annals of the Association of American Geographers, 99, pp. 1033-1044. 